\title{
Analýza vývoje zemědělské krajiny ve vybraných katastrálních územích v horní části povodí Výrovky
}

\section{PAVEL RICHTER}

Klíčová slova: archivní mapy - GIS - land use - mokřady - voda v krajině - zemědělství

\section{SOUHRN}

V tomto článku jsou ve vybraných katastrálních územích s prevažující plochou zemědělské půdy porovnávány aktuální land use a struktura krajiny s historickým stavem z podkladů Císařských povinných otisků stabilního katastru. Jsou zde nastíněny možnosti využití analýz historického vývoje krajiny ke krajinné obnově v zemědělských oblastech, zejména s ohledem na obnovu mokřadních ekosystémů a revitalizaci vodních toků.

\section{ÚVOD - ZMĚNY V KRAJINĚ A ZMĚNY MOKŘADŮ V KONTEXTU KRAJINY}

Krajina se neustále mění. Mění se mj. i její využití a prostorové uspořádání. Tyto změny jsou následkem jak geologických a klimatických procesů, tak i následkem působení člověka na krajinu [1]. V krajině tak můžeme vidět také známky působení různých archeologických kultur, odlišných ekonomických situací a politických událostí [2]. Důležitou a běžnou součástí zemědělsky využívané krajiny byly v minulosti také mokřady, resp. mokré louky. Lokalizace a struktura mokřadů se v čase mění, stejně jako se mění krajina vlivem působení prírodních, ale hlavně antropogenních faktorů. $V$ minulosti lidé na území současné ČR využívali mokřadní biotopy pro svůj prospěch, aniž by je tím ohrožovali nebo do nich nevhodně zasahovali. Pravidelně kosili mokřadní louky a sekali rákos. Pomocí melioračních př́kopů zároveň udržovali optimální vlhkost přírodních mokřadů. V současné době se - až na výjimky - většinou ze strany orgánů ochrany př́rody a krajiny nic podobného neděje. Z naší země tak mokřady, nepočítáme-li rybníky a některé lokality ve zvláště chráněných územích, takřka vymizely [3].

Historické porozumění vzniku mokřadů a jejich dynamice je základním předpokladem pro efektivní opatření pro jejich management, ochranu a obnovu [4]. Vedle vyrovnávání průtoků a filtrace vod a ukládání sedimentů mokřady zmírňují nárazy záplav, redukují erozi a zlepšují kvalitu vody ve vodních tocích. Rozpuštěné nutrienty stejně jako sedimenty z vyvýšených oblastí procházejí na své cestě do říční sítě mokřady a břehovými porosty, kde se postupně odbourávají [5-7].

Nicméně pozitivní role mokřadů byla podceňována, a tudíž $\vee$ průběhu 20. století byly celosvětově mokřadní plochy odvodňovány, zejména pro zemědělské využití. Je odhadováno, že bylo $1,9 \times 10^{6}$ km² z celosvětových prírodních mokřadů preměněno na jiný typ land use [8]. Prakticky všechny řeky a jejich povodí v rozvinutých zemích byly vystaveny změnám. Byly realizovány projekty extenzivního odvodňování ploch (meliorace) nebo byla vyvinuta schémata regulace průtoků, a tím došlo k modifikaci koryt vodních toků. Prímými dopady tohoto působení jsou strměji se svažující koryta, menší nerovnosti dna a z toho vyplývající vyšší průtoková rychlost. Nepřímými dopady jsou pak nižší samočisticí schopnost způsobená nedostatkem mokřadů a zkrácenou dobou toku, nestabilní mělčiny a také akumulace říčních sedimentů. $V$ mnoha případech tato jednání měla za následek zvýšení frekvence a míry záplav, častější období sucha a vyšší stupeň znečištění. Nyní bývají negativní následky těchto činností uznávány a mokřady jsou celosvětově se vzrůstající frekvencí obnovovány, znovužrizovány a chráněny [9].

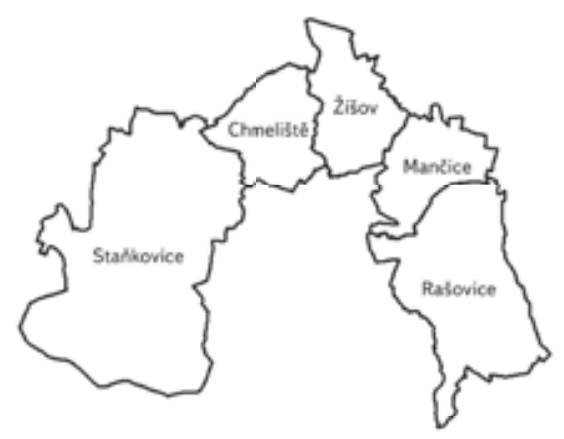

$\square$ Hranice rejených územi: Stabilni katastr 1838-1841

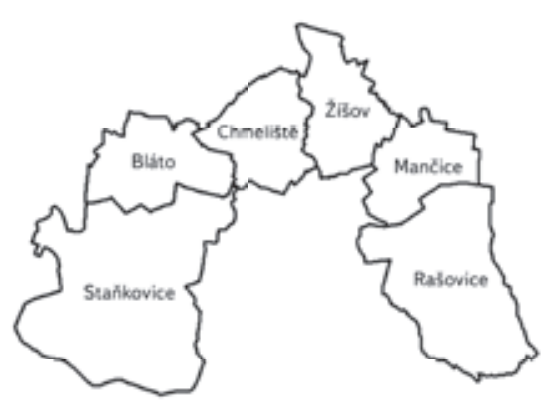

$\square$ Hranice iejenjich úsemí platne hranice katastralnich üzemi

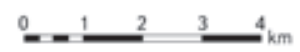

Obr. 1. Řešené území v historických a současných hranicích k. ú. Fig. 1. Examined area in historical and current borders of cadastral territories 


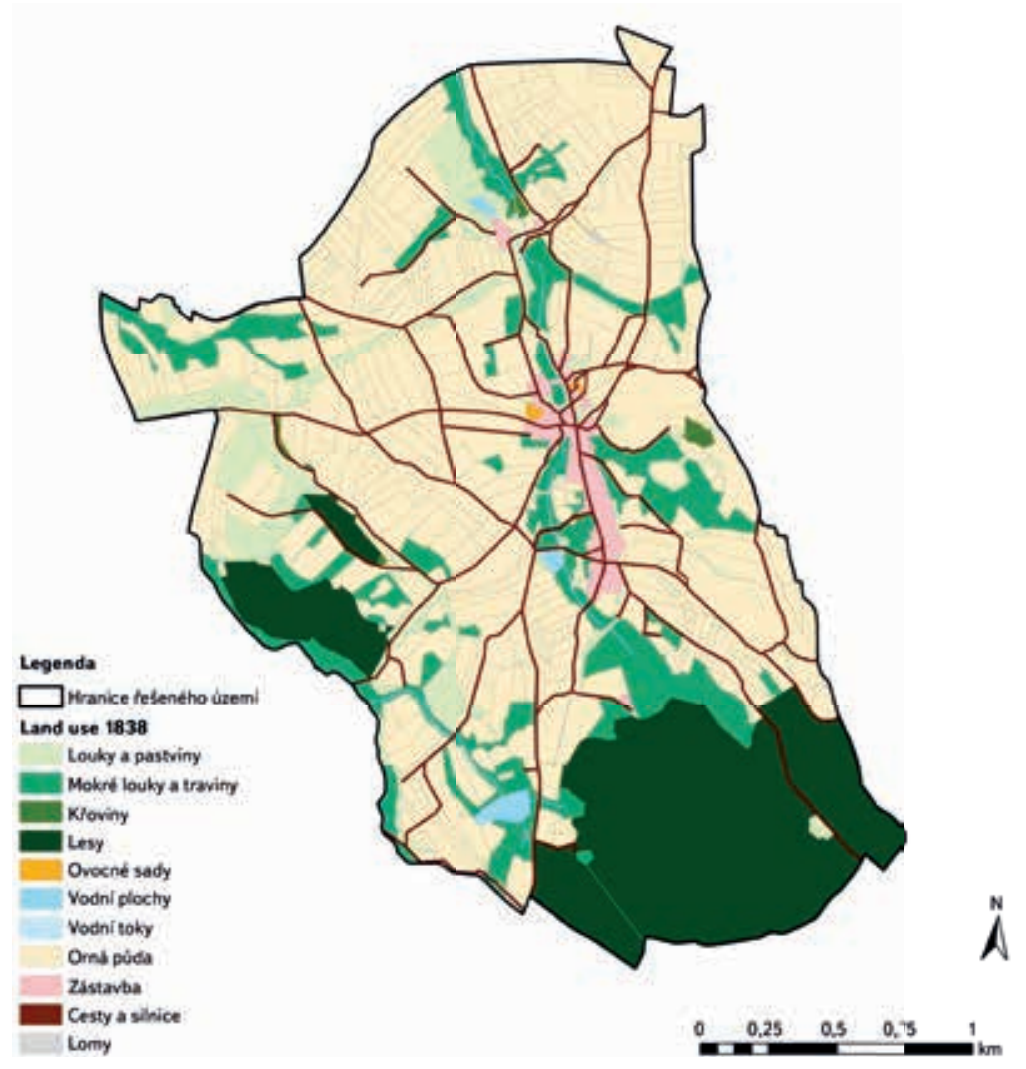

Obr. 2. Zobrazení historického land use v k. ú. Rašovice

Fig. 2. Historical land use in cadastral territory of Rašovice

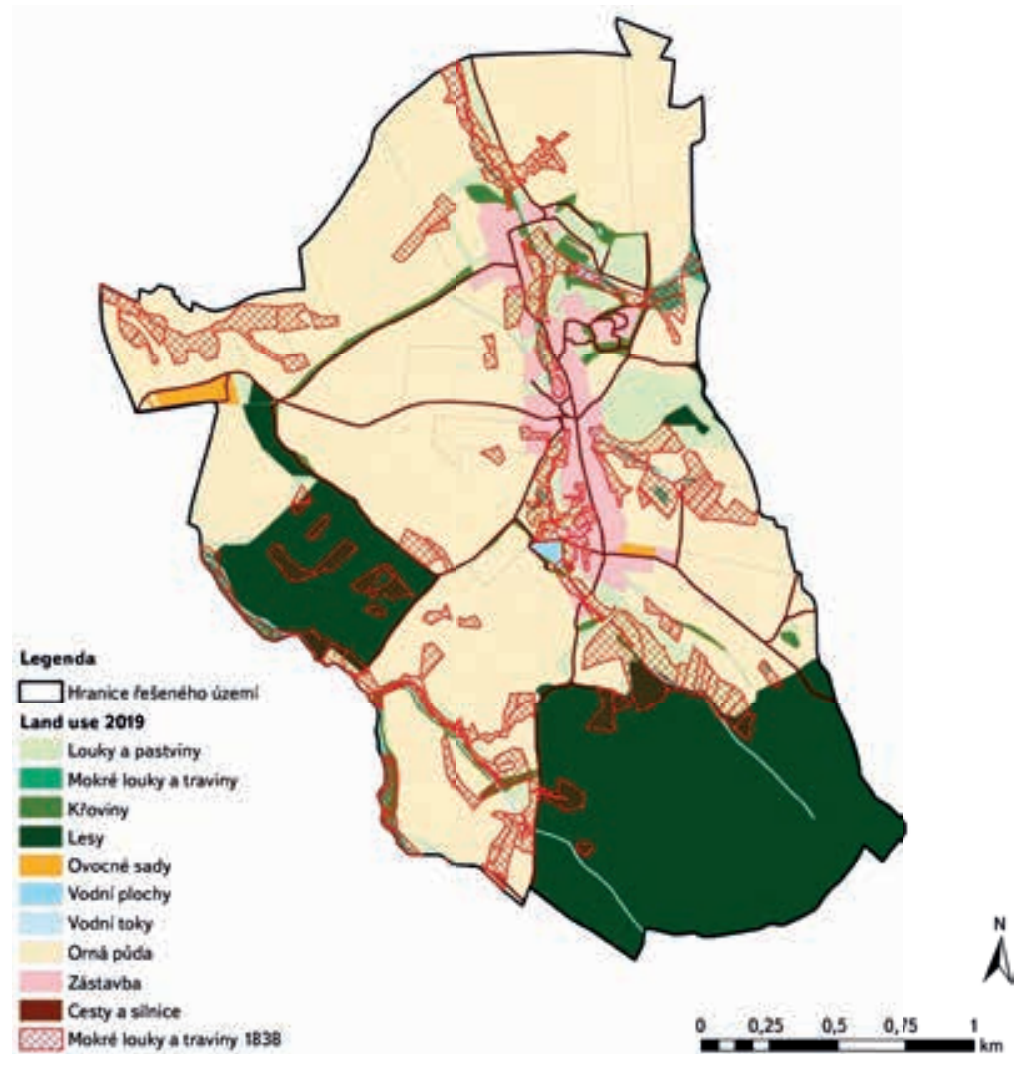

Obr. 3. Zobrazení historických mokrých luk na podkladě současného land use v k. ú. Rašovice

Fig. 3. Historical land use of wet meadows based on current land use in cadastral territory of Rašovice
Při hodnocení stavu krajiny a jejích změn Ize použít bud' land use, což znamená využití území, nebo land cover, což lze interpretovat jako krajinný pokryv. Ovšem definice obou termínů není zcela jednoznačná, resp. těchto definic je celá řada a některé z nich odrážejí také jejich vzájemnou propojenost. Jednou z nejvýstižnějších obecně používaných jednoduchých definic pojmu land use je účel, pro který je krajina využívána. V prípadě termínu land cover je obdobnou definicí pozorovaný, skutečný krajinný pokryv. V této práci bylo zvoleno hodnocení podle land use, protože to dává lepší možnost zahrnout způsob využití krajiny člověkem. Je to výhodnější řešení pro rozdělení travních porostů na mokré a „suché" louky, Ize určit i tzv. sukcesní plochy apod.

\section{GIS JAKO NÁSTROJ PRO PREDIKCI VHODNÝCH PLOCH K OBNOVĚ MOKŘADU゚}

Pokračující klimatické změny mohou zhoršit problémy krajiny ve vztahu k extrémním hydrologickým událostem a míre znečištění. Nicméně cíle udržitelného využití sladkovodních zdrojů vyžadují nové přístupy ve vodním a říčním managementu v povodí, jež budou brát v úvahu také funkci mokřadů [9].

$\checkmark$ současné době se zvyšuje počet aktivit zaměřených na obnovu mokřadů jako multifunkčních krajinných prvků. Mokřady jsou ceněny pro svůj vysoký retenční potenciál a jejich jedinečnou biologickou rozmanitost. Úspěch obnovy mokřadů však zřetelně závisí na výběru místa vhodného pro dosažení konkrétních cílů obnovy. K tomu Ize jako vhodný nástroj využít geografické informační systémy (GIS), které se stávají čím dál více užitečným nástrojem při realizaci environmentálního managementu [10].

\section{ŘEŠENÉ ÚZEMÍ}

Krajinný vývoj byl hodnocen na území sousedních historických katastrálních území (k. ú.) Rašovice, Mančice, Žíšov, Chmeliště a Staňkovice. Hodnocenou lokalitou je území o celkové výměře 2444,94 ha. Nadmořská výška tohoto území se pohybuje mezi 380 a 530 metry. Oblast se nachází na horním toku Výrovky v povodí Labe a leží v mírně zvIněné planině klesající pozvolna do Polabské nížiny. Do bezprostřední blízkosti lokality zasahují z jihovýchodu poslední výběžky Českomoravské vrchoviny a Středočeské pahorkatiny. Z hlediska pedologického se na území vyskytují, podle klasifikace komplexního průzkumu půd (KPP), plochy hnědé půdy, ilimerizované půdy a oglejené půdy, v okolí vodních toků se nacházejí drnoglejová půda a nivní půda glejová [11]. Hodnocená oblast leží převážně v klimatickém regionu MT2 (mírně teplý, mírně vlhký), jen převážná část k. ú. Rašovice a malá část lesních pozemků v k. ú. Staňkovice se nachází v klimatickém regionu MT4 (mírně teplý) [12]. Z dat, jimiž jsou charakterizovány klimatické regiony v rámci BPEJ [13], vyplývá, že se oba klimatické regiony v oblasti teplot liší jen nepatrně, ale v oblasti srážek a hrozícího sucha se převážná část řešeného území nachází v méně příznivém klimatickém regionu (tab. 1). Dle správního členění patří toto území k okresu Kutná Hora ve Středočeském kraji.

Řešenák.ú. prošla určitýmizměnami ohlednějejich hranic. Nejmarkantnějšími změnami prošlo k. ú. Rašovice, jehož oficiální název je nyní Rašovice u Uhlî̌ských Janovic. K. ú. Rašovice prošlo od roku 1839 několika proměnami, původní území z roku 1839 zasahovalo na jižním okraji až k obci Sudějov, jednalo se převážně o lesní pozemky. Toto území patři v současnosti k. ú. Sudějov. Další změnou prošla hranice $s$ k. ú. Uhlírské Janovice. Do roku 2006 byly provedeny drobné změny, žrejmě v důsledku změny koryta Annenského potoka, jenž tvořil v roce 1839 podstatnou část hranice mezi těmito k. ú. Po roce 2006 došlo pak k výměně části území mezi k. ú. Rašovice a k. ú. Uhlî̌ské Janovice. Jednalo se opět o důsledky změny koryta vodního toku a také o pozemky orné půdy, kde hranice vedla uprostřed polí po hranici pozemků. Jelikož však tyto hranice 
Tab. 1. Charakteristika klimatických regionů v řešeném území

Tab. 1. Characteristics of climatic regions in the examined area

\begin{tabular}{llllll} 
Kód regionu & $\begin{array}{l}\text { Charakteristika } \\
\text { regionu }\end{array}$ & $\begin{array}{l}\text { Suma teplot } \\
\text { nad } 10^{\circ} \mathbf{C}\end{array}$ & $\begin{array}{l}\text { Průměrná roční } \\
\text { teplota }\left[{ }^{\circ} \mathbf{C}\right]\end{array}$ & $\begin{array}{l}\text { Průměrný roční } \\
\text { úhrn srážek [mm] }\end{array}$ & $\begin{array}{l}\text { Pravděpodobnost suchých } \\
\text { vegetačních období }[\%]\end{array}$ \\
\hline MT2 & $\begin{array}{l}\text { mírně teplý, } \\
\text { mírně vlhký }\end{array}$ & $2200-2500$ & $7-8$ & $550-650(700)$ & $15-30$ \\
\hline MT4 & mírně teplý, vlhký & $2200-2400$ & $6-7$ & $650-750$ & $5-15$
\end{tabular}

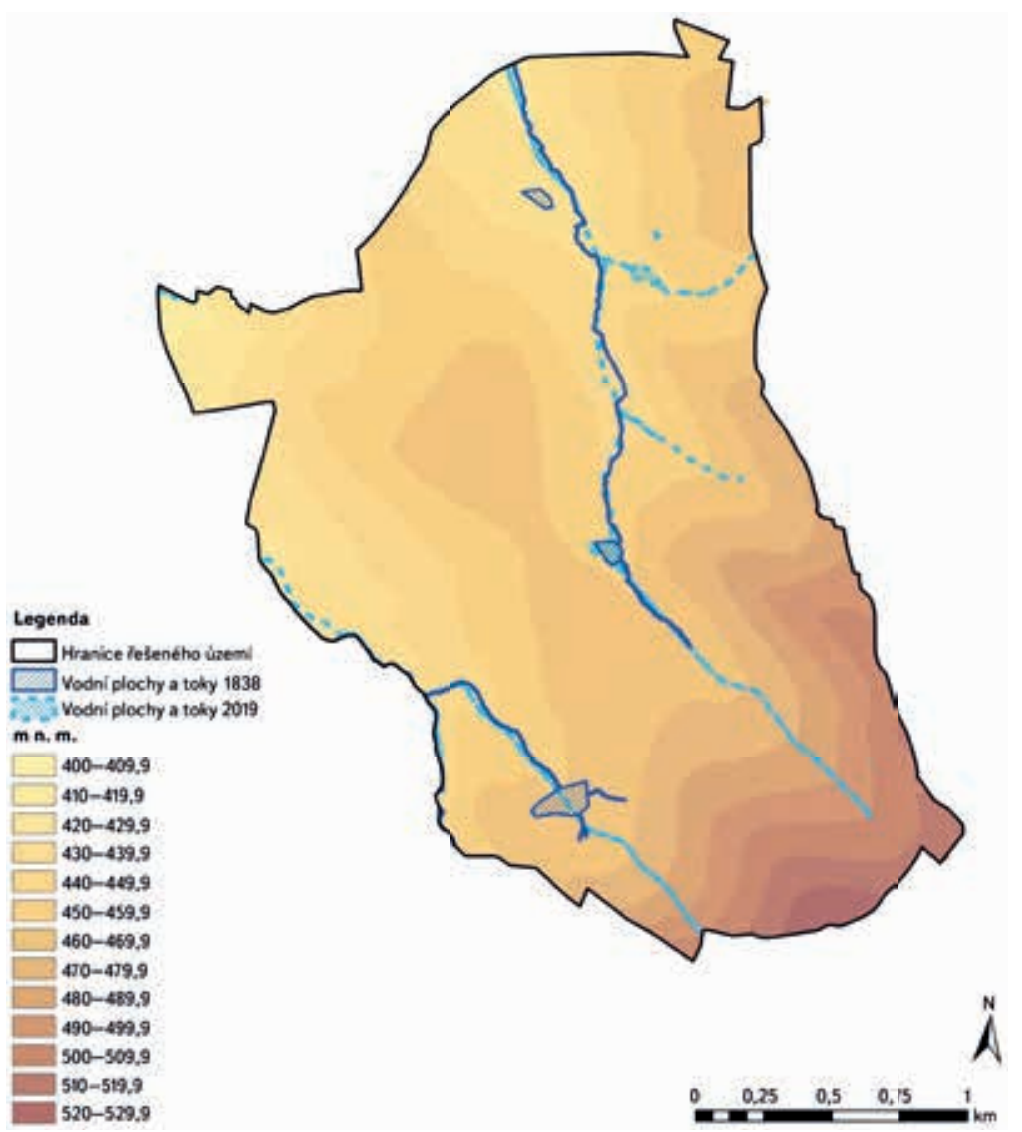

Obr. 4. Porovnání historické a současné lokalizace vodních ploch a toků v k. ú. Rašovice Fig. 4. The comparison of historical and current localization of water reservoirs and watercourses in cadastral territory of Rašovice

nemají v současné době větší význam a nacházejí se na území velkých obhospodařovaných ploch, došlo ke směně pozemků a posunutí hranic k lesu, resp. vodnímu toku. Obdobně došlo ke směně mezi k. ú. Rašovice a k. ú. Křečovice, kde se jednalo jen o menší pozemky zemědělské půdy a došlo k vyhlazení linie vzájemných hranic v lokalitě poblíz Netušilu. Poslední změnou bylo převedení větší plochy orné půdy z k. ú. Mančice pod k. ú. Rašovice. Většími změnami prošlo také k. ú. Mančice, ale tyto změny byly ve značné míře v souvislosti se změnami k. ú. Rašovice [14, 15]. Hranice k. ú. Žíšov, Chmeliště a Staňkovice nedoznaly takřka žádných změn. Podstatnou změnou byl ale vznik k. ú. Blato na části historického k. ú. Staňkovice. Historické a současné hranice k. ú v řešeném území jsou znázorněny na obr. 1. Ačkoli v současné době všechna řešená k. ú. patří k jednomu kraji (Středočeskému) a okresu (Kutná Hora), historicky patřila k. ú. Rašovice, Mančice a Žišov ke kraji Čáslavskému, zatímco k. ú. Chmeliště a Staňkovice náležela ke kraji Kouřimskému.
Tab. 2. Rozděleníploch v řšeném územípodle land use včetnějejich stručnéspecifikace Tab. 2. Distribution of the examined area according to the land use, including its brief specification

\begin{tabular}{|c|c|}
\hline Land use & Specifikace \\
\hline \multicolumn{2}{|c|}{ Plochy relativně stabilní } \\
\hline Louky a pastviny & $\begin{array}{l}\text { Louky, pastviny a zemědělsky nevyužívané } \\
\text { zatravněné plochy }\end{array}$ \\
\hline Mokré louky & Podmáčené lokality s travním porostem \\
\hline Křoviny & $\begin{array}{l}\text { Dřevinná společenstva, jež nebyla klasifikována } \\
\text { jako les či sad }\end{array}$ \\
\hline Sukcesní plochy & $\begin{array}{l}\text { Plochy ponechané sukcesi (převážně ruderální } \\
\text { lokality) }\end{array}$ \\
\hline Lesy & Plochy se zapojenou dřevinnou vegetací \\
\hline Ovocné sady & Ovocné sady včetně zahrad mimo intravilán \\
\hline Vodní plochy & Rybníky a nádrže \\
\hline Vodní toky & Potoky a odvodňovací kanály \\
\hline \multicolumn{2}{|c|}{ Plochy relativně nestabilní } \\
\hline Orná půda & Pravidelně obdělávaná pưda \\
\hline Zástavba & Intravilán obcí včetně zahrad, vyjma komunikací \\
\hline Cesty a silnice & Silnice všech tříd, polní a lesní cesty \\
\hline Lomy & Kamenolomy \\
\hline Těžební prostory & Zde oficiálně nezrušený těžební prostor cihelny \\
\hline Skládky & Skládky komunálního nebo stavebního odpadu \\
\hline Železnice & Železniční trat’ včetně náspů \\
\hline
\end{tabular}

\section{METODIKA}

Vzhledem k obecně známým skutečnostem a trendům týkajícím se vývoje zemědělsky využívané krajiny na území současné ČR a historickým souvislostem (např. zazemňování vodních ploch, kolektivizace zemědělství, socializace venkova, napřimování vodních toků, meliorace, likvidace mokřadů a niv vodních toků) směřujícím k získání dalších ploch orné půdy a jejímu snadnějšímu 


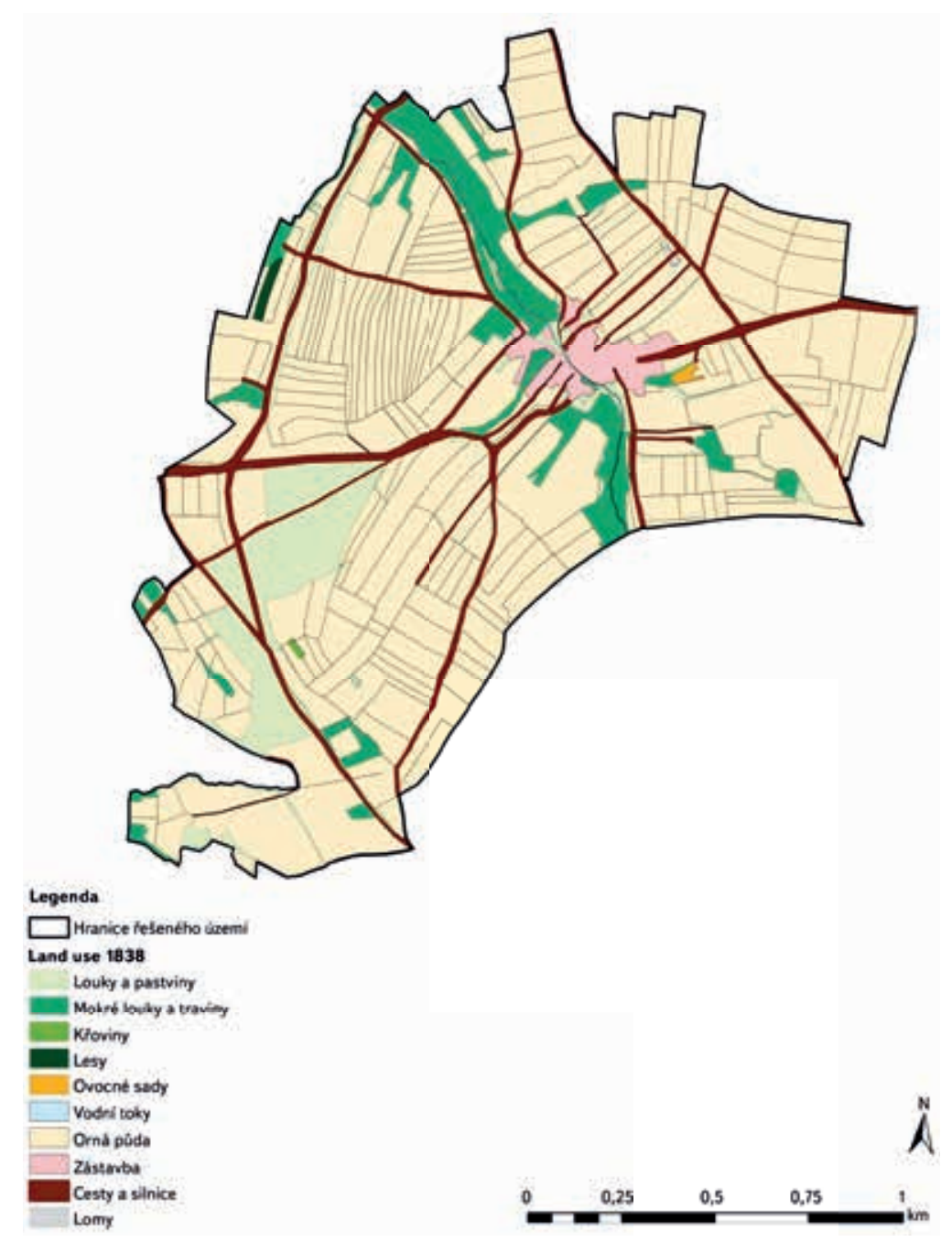

Obr. 5. Zobrazení historického land use v k. ú. Mančice

Fig. 5. Historical land use in cadastral territory of Mančice

obhospodařování stále robustnější technikou byly stanoveny očekávané trendy ve vývoji krajiny $v$ řešeném území. $\vee$ rámci hodnocení vývoje krajiny $\vee$ tomto území byly řešeny tyto hlavní výzkumné otázky a hypotézy:

— H1: V řešeném území se výrazně zmenšila rozloha mokrých luk. Toto snížení je výraznější v části patřící do klimatického regionu MT2 oproti části patřící do klimatického regionu MT4.

- H2: V řešeném území se u land use orná půda zvětšila celková rozloha, prưměrná velikost plošky a snížil se počet plošek.

- H3: V řešeném území se zmenšila rozloha vodních ploch.

— H4: V rešeném území se zkrátila délka vodních toků.

\section{Podklady pro zpracování dat}

Základním podkladem pro tvorbu vektorové vrstvy pro analýzu vývoje řešených území byly mapové listy Císařských povinných otisků stabilního katastru (znázorňující stav v roce 1838, resp. 1841 v měřítku 1 : 2880) [16] a souřadnicově připojená ortofotomapa (z roku 2019) a Základní mapa ČR 1 : 10000 (ZM 10), obě dostupné na Geoportálu ČÚZK [17] prostřednictvím WMS služby.

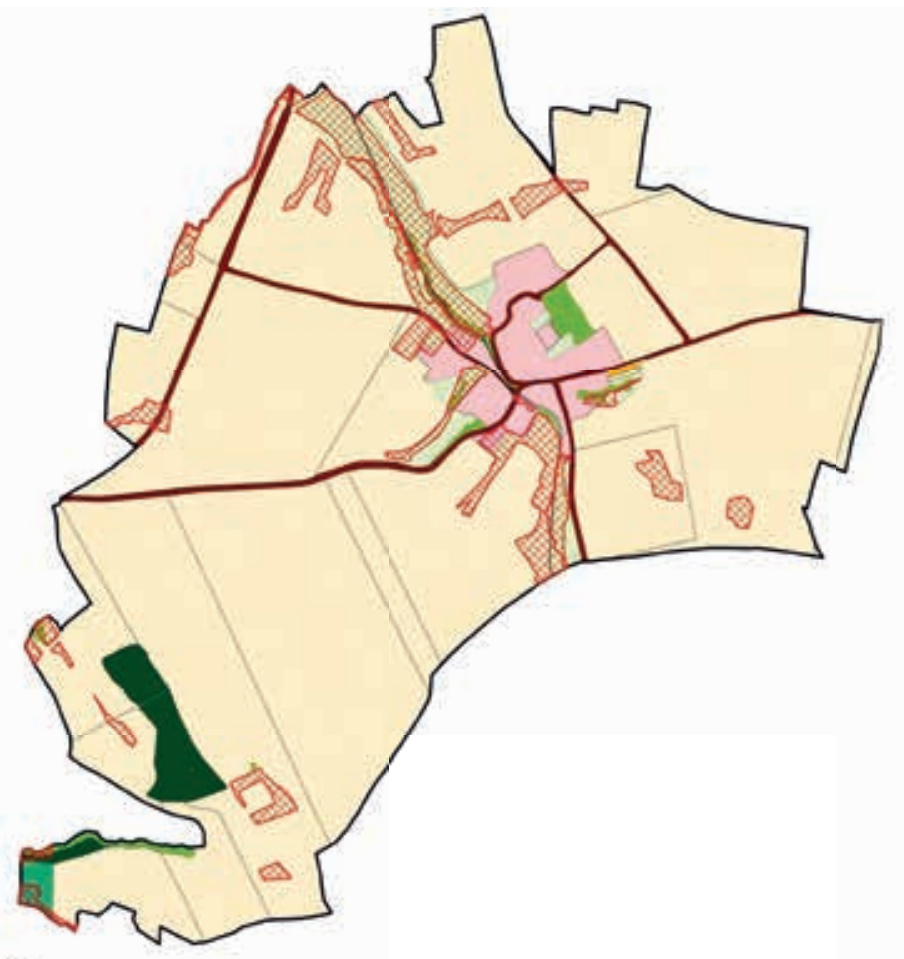

Legenda
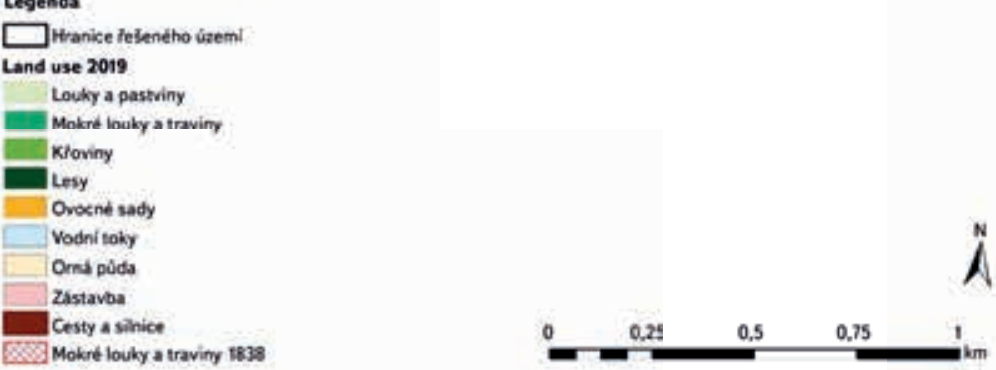

Obr. 6. Zobrazení historických mokrých luk na podkladě současného land use v k. ú. Mančice

Fig. 6. Historical land use of wet meadows based on current land use in cadastral territory of Mančice

\section{Použité programy a zpracování dat}

Georeferencování archivních mapových podkladů a připojení současných podkladů pomocí WMS služby a následná tvorba polygonové vrstvy formátu .shp proběhlo v prostředí ArcGIS, konkrétně v programu ArcMAP 10.7.1. Každý polygon byl přesně definován svým identifikačním číslem a rokem, ve kterém se v území vyskytoval. Podle údaje o príslušnosti k roku došlo k vyobrazení hranic jednotlivých polygonů. Prvotní zpracování dat proběhlo v prostředí GIS, jednalo se o výpočet plochy polygonů a délek linií. Výsledné hodnoty byly poté vyexportovány do prostředí programu Microsoft Excel 2016 a zde byly promítnuty do tabulek. $V$ rámci zpracování těchto mapových a tabelárních výstupů jsou tu prezentovány výsledky týkající se změny rozlohy, resp. délky a lokalizace mokrých luk, vodních ploch a vodních toků. V tabulce jsou také zveřejněny údaje o vývoji rozlohy orné půdy jako hlavního ukazatele rozsahu zemědělského hospodaření. 


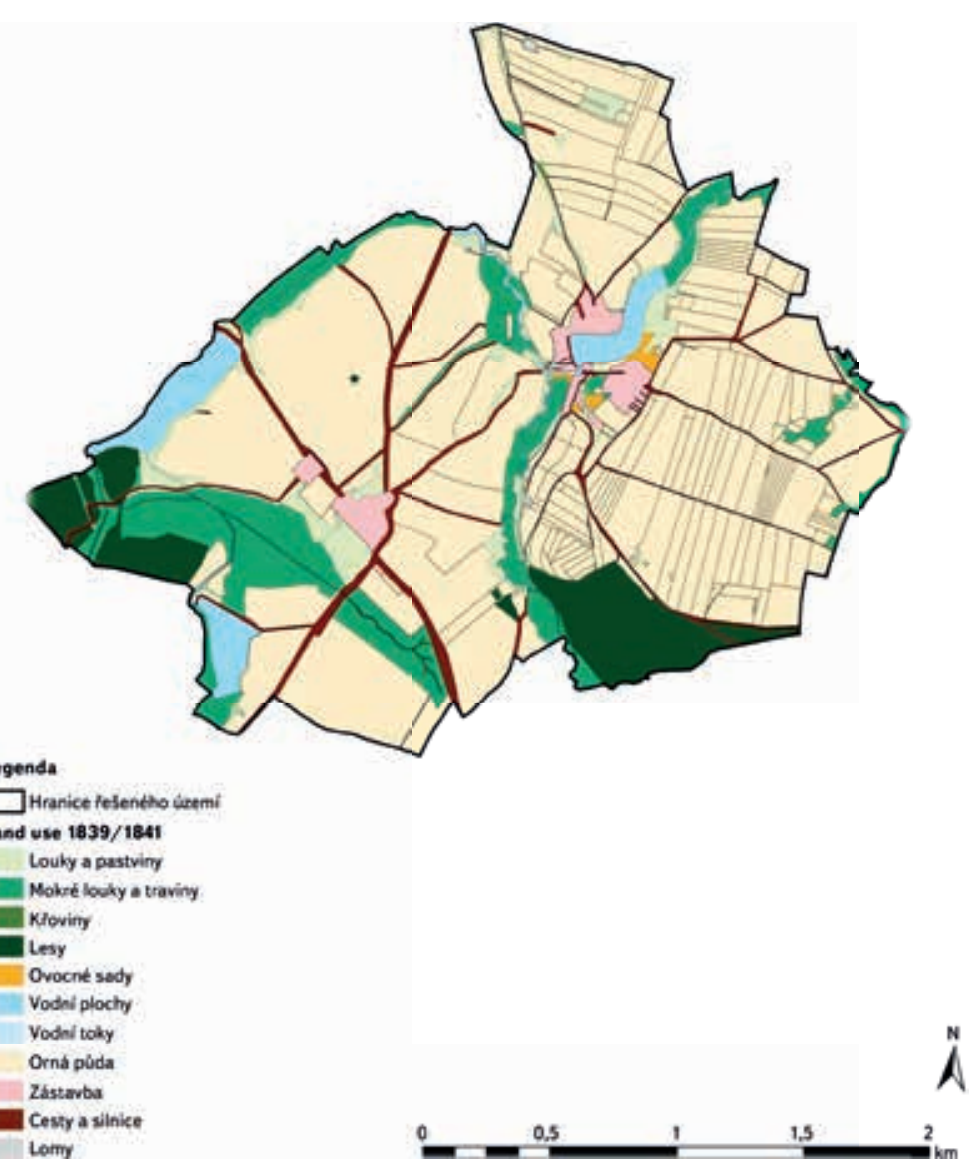

Obr. 7. Zobrazení historického land use v k. ú. Chmeliště a Žišov

Fig. 7. Historical land use in cadastral territories of Chmeliště and Žišov

\section{HODNOCENÍ VÝVOJE KRAJINY A VYMEZENÍ LAND USE TYPU゚}

Vyhodnocení proběhlo pro jednotlivá k. ú. podle historických hranic. Výjimkou bylo sloučení k. ú. Chmeliště a Žíšov z důvodu lepšího vyhodnocení krajinných struktur. A to přesto, že každé území má historické mapové podklady z jiného roku. Hranici mezi těmito katastry totiž tvoří vodní tok Výrovka, a z hlediska krajinných struktur tedy tvoří kompaktní území. A změna byla také u k. ú. Rašovice, kde se již nepočítalo s lesnatým výběžkem území připojeným později ke k. ú. Sudějov.

V řešeném území bylo vymezeno 15 land use typů a ty pak byly dále děleny z hlediska ekologické stability na plochy relativně stabilní a relativně nestabilní (tab. 2). Vymezení land use typů vycházelo z legendy historických mapových podkladů stabilního katastru. Navíc byly vymezeny land use typy "Sukcesní plochy", a také "Železnice", "Těžební prostory“ a "Skládky". Za sukcesní plochy byly považovány plochy, jež se budou v blízké budoucnosti zřejmě klasifikovat jako křoviny a které jsou - vědomě či mimoděk - ponechány sukcesnímu vývoji. Zde se jednalo o vytěžené území cihelny ve Chmelišti, jež bylo ponecháno sukcesi v sousedství několika nově vzniklých malých vodních ploch. A také o některé plochy v okolí staveb bývalých či současných zemědělských družstev. Mokré louky byly v současnosti určeny na základě mapových podkladů ZM10, současné ortofotomapy a terénního průzkumu. Orná půda je rozdělena na jednotlivé plochy podle pěstovaných plodin, nikoli podle vlastnické struktury, zatímco v roce 1838, resp. 1841, byly zaznamenány všechny plošky tak, jak jsou zakresleny v mapách

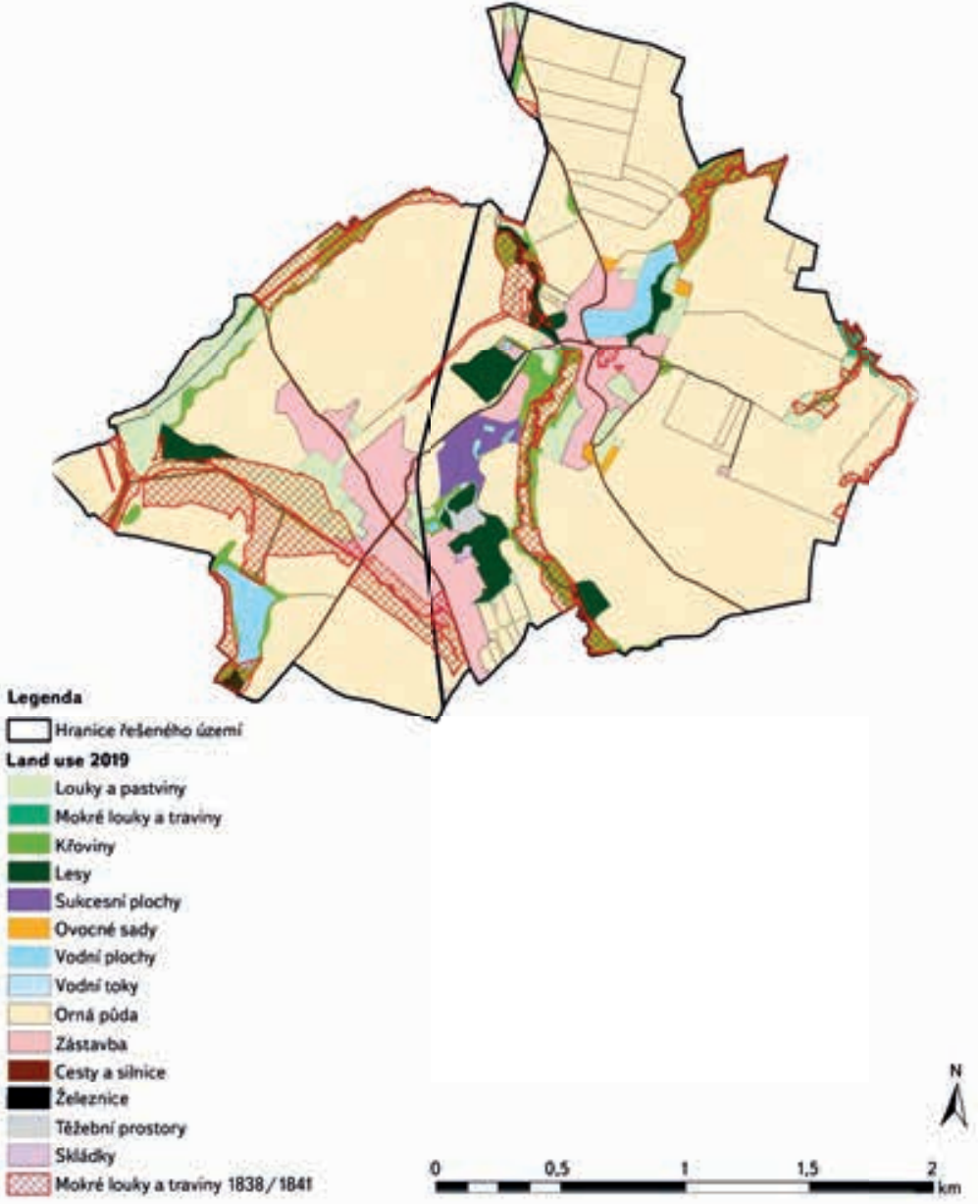

Obr. 8. Zobrazení historických mokrých luk na podkladě současného land use v k. ú. Chmeliště a Žíšov

Fig. 8. Historical land use of wet meadows based on current land use in cadastral territories of Chmeliště and Žíšov

Císařských otisků stabilního katastru. U všech land use typů, s výjimkou vodních toků, byly vypočteny a následně vyhodnoceny následující charakteristiky:

— rozloha jednotlivých land use typů [ha]

- počty plošek jednotlivých land use typů [ks]

- průměrná velikost plošky land use typu [ha]

— poměr rozlohy land use typu k celkové ploše řešeného území [\%]

- poměr rozlohy land use typu k výchozímu stavu téhož land use typu v roce 1838, resp. 1841 [\%]

U land use typu vodní toky byly charakteristiky týkající se počtu a velikosti plošek nahrazeny údajem o souhrnné délce těchto typů na řešeném území. Hodnocení změn struktury krajiny na úrovni land use bylo provedeno na základě porovnání a následné kvantifikace dat v jednotlivých časových obdobích.

\section{VÝSLEDKY}

Pro všechna řešená k. ú. je společným znakem výrazný pokles počtu plošek orné půdy a mokrých luk. Zatímco ale také významně vzrostla průměrná velikost plošek orné půdy, u mokrých luk je průměrná velikost plošky v současnosti stejná nebo téměř stejná jako v minulosti s výjimkou k. ú. Staňkovice, kde je v současnosti zhruba třetinová v porovnání s historickou hodnotou (tab. 3). 


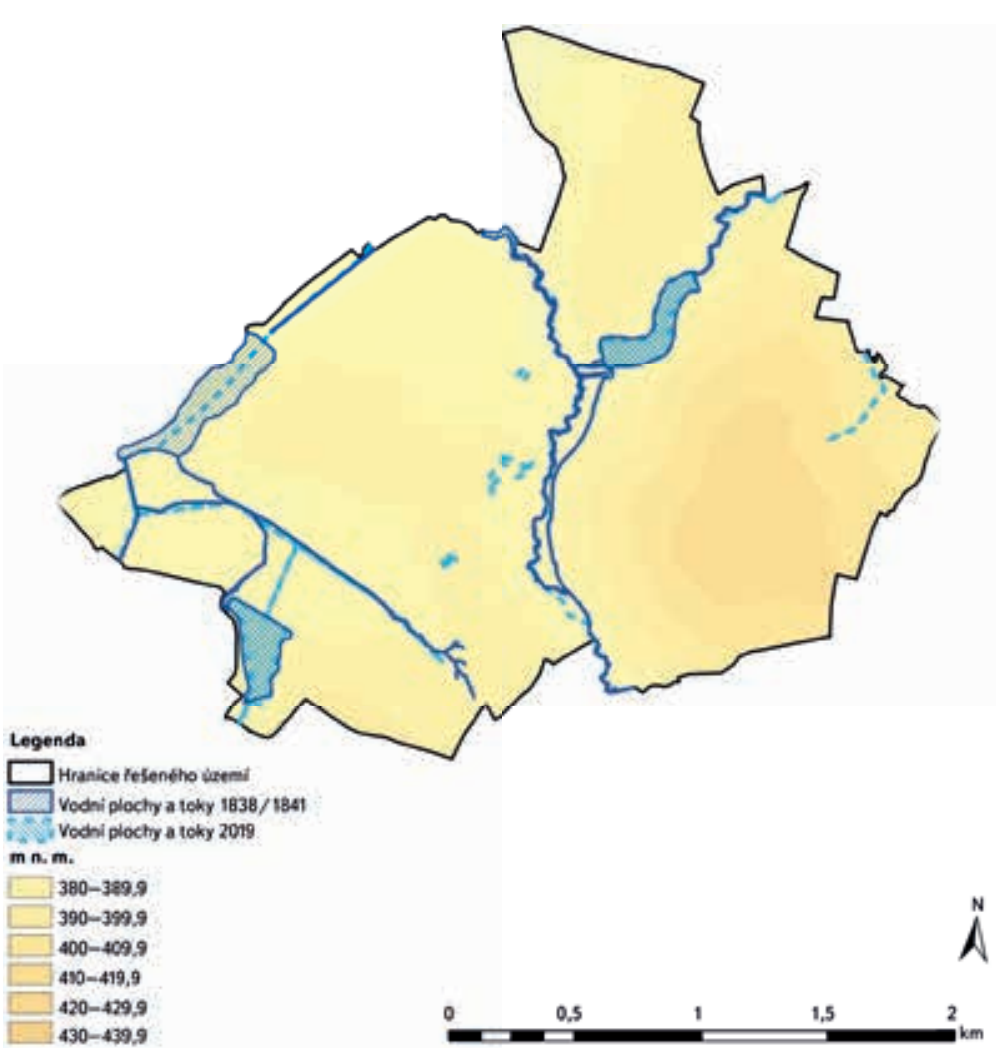

Obr. 9. Porovnání historické a současné lokalizace vodních ploch a toků v k. ú. Chmeliště a Žíšov

Fig. 9. The comparison of historical and current localization of water reservoirs and watercourses in cadastral territories of Chmeliště and Žíšov

\section{RAŠOVICE}

Současný název území je Rašovice u Uhliřských Janovic. Na tomto území došlo k výraznému úbytku mokrých luk na 7,9 \% historické rozlohy a zároveň k mírnému úbytku orné půdy; vodní plochy přišly o polovinu své historické rozlohy. Vodní toky měly rozlohu totožnou a kupodivu měly také větší délku v současnosti než v minulosti (tab. 3, obr. 4). Mokré louky byly nahrazeny převážně ornou půdou, v menší míre pak loukami, lesem a zástavbou (obr. 2 a 3).

\section{MANČICE}

Současný název území je Mančice u Rašovic, jedná se o typicky zemědělsky využívané území, kde je v podstatě pouze zástavba a orná půda. Zde došlo k nárůstu plochy orné půdy a mokré louky téměř vymizely. Jsou nahrazeny převážně ornou půdou, ale také loukami při vodních tocích (obr. 5 a 6). Vodní plochy se zde nevyskytovaly a vodní toky mají téměř totožnou délku, jejich plocha je však v současnosti zhruba poloviční (tab. 3).

\section{CHMELIŠTĚ A ŽÍŠOV}

Zde došlo k nárůstu plochy orné půdy a velkému úbytku mokrých luk a vodních ploch. Vodní toky jsou oproti minulosti kratší a zaujímají výrazně menši plochu (tab. 3, obr. 9). Bývaly napřimovány již v minulosti, ovšem bylo to $v$ rámci jejich lokalizace uprostřed mokrých luk. Mokré louky byly nahrazeny převážně ornou půdou, ale též zástavbou, krovinami a lukami (obr. 7 a 8).

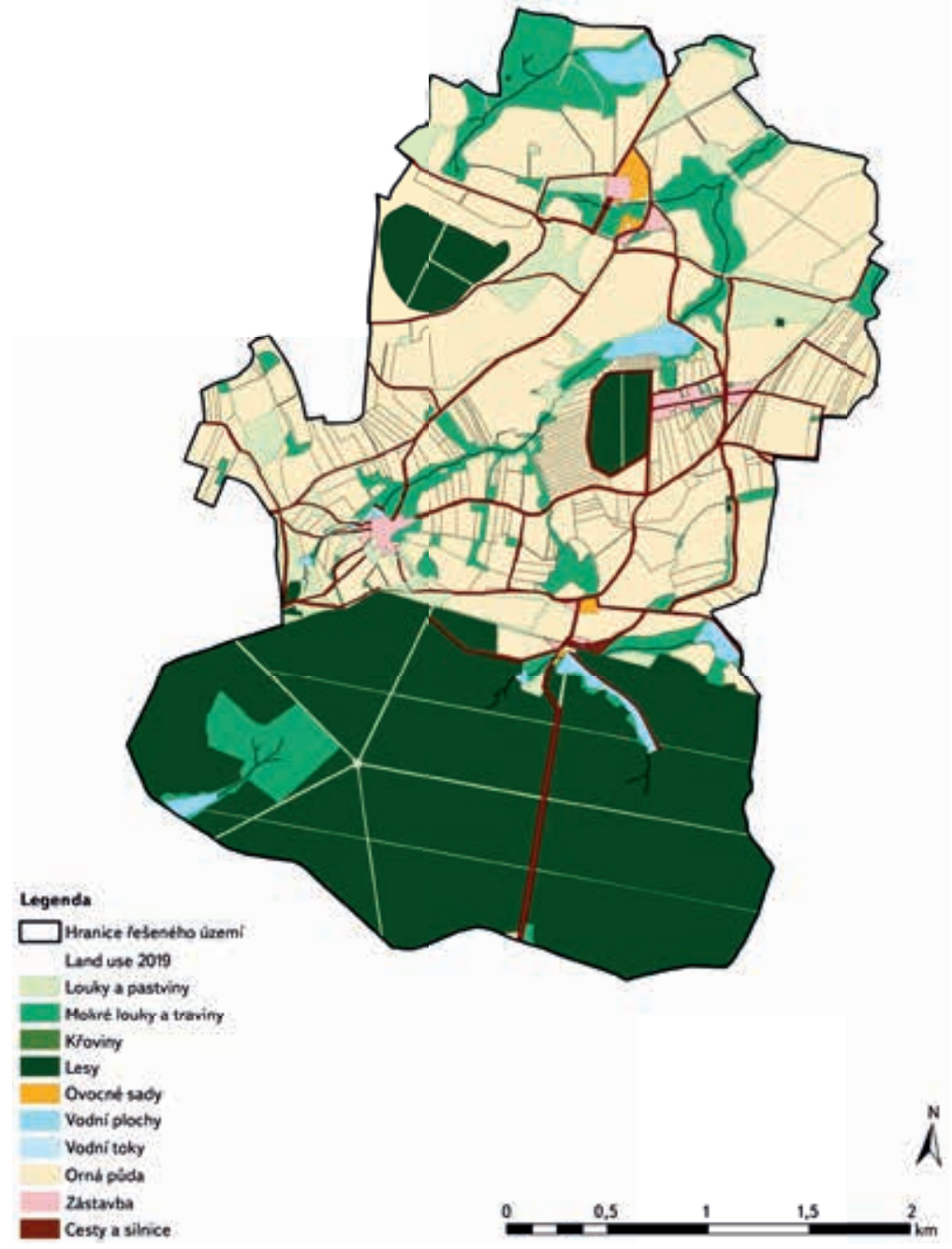

Obr. 10. Zobrazení historického land use v k. ú. Staňkovice

Fig. 10. Historical land use in cadastral territory of Staňkovice

\section{STAŇKOVICE}

Na území historického k. ú. Staňkovice se v současné době nacházejí k. ú. Staňkovice a Bláto. Na tomto území došlo k výraznému nárůstu plochy orné půdy a velkému úbytku mokrých luk. Vodní plochy se zmenšily zhruba o pětinu. Vodní toky mají téměř totožnou délku, ale plocha je v současnosti zhruba tretinová (tab.3, obr. 12). Mokré louky byly nahrazeny prevážně ornou půdou, v menší míre lesem, vodní plochou, loukami a křovinami (obr. 10 a 11).

\section{DISKUZE}

Při zvoleném hodnocení krajiny podle land use docházelo k určitým rozdílům oproti tomu, kdyby bylo hodnocení provedeno podle land cover. Napríklad podmáčená lokalita v k. ú. Rašovice na místě historického prameniště nebyla hodnocena jako sukcesní plocha, i když to lépe odpovídá skutečnosti. Ovšem na současné ZM 10 je stále zobrazena jen orná půda a snahou zemědělců obhospodařujících tento pozemek bylo (v době zpracování výsledků) tuto lokalitu stále obdělávat. Pokud by tato lokalita byla uznána jako sukcesní plocha, v př́padě jejího managementu spiše jako mokrá louka, zmenšila by se současná rozloha land use hodnoceného jako orná půda v k. ú. Rašovice o téměř 2 ha, tj. o 0,66 \%. Rovněž jde o určení sukcesních ploch ve stále ještě nezrušeném 
Tab. 3. Vyhodnocení vývoje vybraných krajinných struktur na řešeném území

Tab. 3. Evaluation of the development of selected landscape structures in the examined area

\section{Rašovice (547,24 ha)}

\begin{tabular}{|c|c|c|c|c|c|c|c|c|}
\hline \multirow{2}{*}{$\begin{array}{l}\text { Land use } \\
\text { Rok }\end{array}$} & \multicolumn{2}{|c|}{ Orná půda } & \multicolumn{2}{|c|}{ Mokré louky } & \multicolumn{2}{|c|}{ Vodní plochy } & \multicolumn{2}{|c|}{ Vodní toky } \\
\hline & 1838 & 2019 & 1838 & 2019 & 1838 & 2019 & 1838 & 2019 \\
\hline Výměra [ha] & 303,6 & 299 & 69,3 & 5,5 & 2,6 & 1,3 & 1,2 & 1,4 \\
\hline Počet plošek [ks] & 469 & 32 & 141 & 14 & 3 & 3 & - & - \\
\hline Průměrná velikost plošky [ha] & 0,7 & 9,4 & 0,5 & 0,4 & 0,9 & 0,4 & - & - \\
\hline Délka [km] & - & - & - & - & - & - & 5,33 & 6,99 \\
\hline Poměr k celkové ploše [\%] & 55,5 & 54,6 & 12,7 & 1 & 0,5 & 0,2 & 0,2 & 0,2 \\
\hline Výměra proti roku 1838 [\%] & 100 & 98,5 & 100 & 7,9 & 100 & 45,7 & 100 & 117 \\
\hline
\end{tabular}

\section{Mančice (246,9 ha)}

\begin{tabular}{|c|c|c|c|c|c|c|c|c|}
\hline \multirow{2}{*}{$\begin{array}{l}\text { Land use } \\
\text { Rok }\end{array}$} & \multicolumn{2}{|c|}{ Orná půda } & \multicolumn{2}{|c|}{ Mokré louky } & \multicolumn{2}{|c|}{ Vodní plochy } & \multicolumn{2}{|c|}{ Vodní toky } \\
\hline & 1838 & 2019 & 1838 & 2019 & 1838 & 2019 & 1838 & 2019 \\
\hline Výměra [ha] & 189,2 & 212,1 & 18,4 & 0,7 & - & - & 0,5 & 0,2 \\
\hline Počet plošek [ks] & 237 & 23 & 31 & 1 & - & - & - & - \\
\hline Průměrná velikost plošky [ha] & 0,8 & 9,2 & 0,6 & 0,7 & - & - & - & - \\
\hline Délka [km] & - & - & - & - & - & - & 1,5 & 1,4 \\
\hline Poměr k celkové ploše [\%] & 76,6 & 85,9 & 7,5 & 0,3 & - & - & 0,2 & 0,1 \\
\hline Výměra proti roku 1838 [\%] & 100 & 112,1 & 100 & 3,8 & - & - & 100 & 40 \\
\hline
\end{tabular}

\section{Chmeliště a Žíšov $(528,7$ ha)}

\begin{tabular}{|c|c|c|c|c|c|c|c|c|}
\hline \multirow{2}{*}{$\begin{array}{l}\text { Land use } \\
\text { Rok }\end{array}$} & \multicolumn{2}{|c|}{ Orná půda } & \multicolumn{2}{|c|}{ Mokré louky } & \multicolumn{2}{|c|}{ Vodní plochy } & \multicolumn{2}{|c|}{ Vodní toky } \\
\hline & $1838 / 41$ & 2019 & $1838 / 41$ & 2019 & $1838 / 41$ & 2019 & $1838 / 41$ & 2019 \\
\hline Výměra [ha] & 353,5 & 372,3 & 60,1 & 1,5 & 18,5 & 10,1 & 4,2 & 0,9 \\
\hline Počet plošek [ks] & 217 & 58 & 40 & 1 & 3 & 7 & - & - \\
\hline Průměrná velikost plošky [ha] & 1,6 & 6,4 & 1,5 & 1,5 & 6,2 & 1,4 & - & - \\
\hline Délka [km] & - & - & - & - & - & - & 8,33 & 7,1 \\
\hline Poměr k celkové ploše [\%] & 66,9 & 70,4 & 11,4 & 0,3 & 3,5 & 1,9 & 0,8 & 0,2 \\
\hline Výměra proti roku 1838/1841 [\%] & 100 & 105,3 & 100 & 2,5 & 100 & 54,6 & 100 & 21 \\
\hline \multicolumn{9}{|l|}{ Staňkovice (1122,1 ha) } \\
\hline Land use & \multicolumn{2}{|c|}{ Orná půda } & \multicolumn{2}{|c|}{ Mokré louky } & \multicolumn{2}{|c|}{ Vodní plochy } & \multicolumn{2}{|c|}{ Vodní toky } \\
\hline Rok & 1841 & 2019 & 1841 & 2019 & 1841 & 2019 & 1841 & 2019 \\
\hline Výměra [ha] & 453,8 & 570,8 & 109,5 & 1 & 19,5 & 14,4 & 2 & 0,7 \\
\hline Počet plošek [ks] & 322 & 49 & 80 & 2 & 15 & 9 & - & - \\
\hline Průměrná velikost plošky [ha] & 1,41 & 11,7 & 1,4 & 0,5 & 1,3 & 1,6 & - & - \\
\hline Délka [km] & - & - & - & - & - & - & 7,9 & 7,5 \\
\hline Poměr k celkové ploše [\%] & 40,5 & 50,9 & 9,8 & 0,1 & 1,8 & 1,3 & 0,2 & 0,1 \\
\hline Výměra proti roku 1841 [\%] & 100 & 125,8 & 100 & 0,9 & 100 & 73,9 & 100 & 35 \\
\hline
\end{tabular}




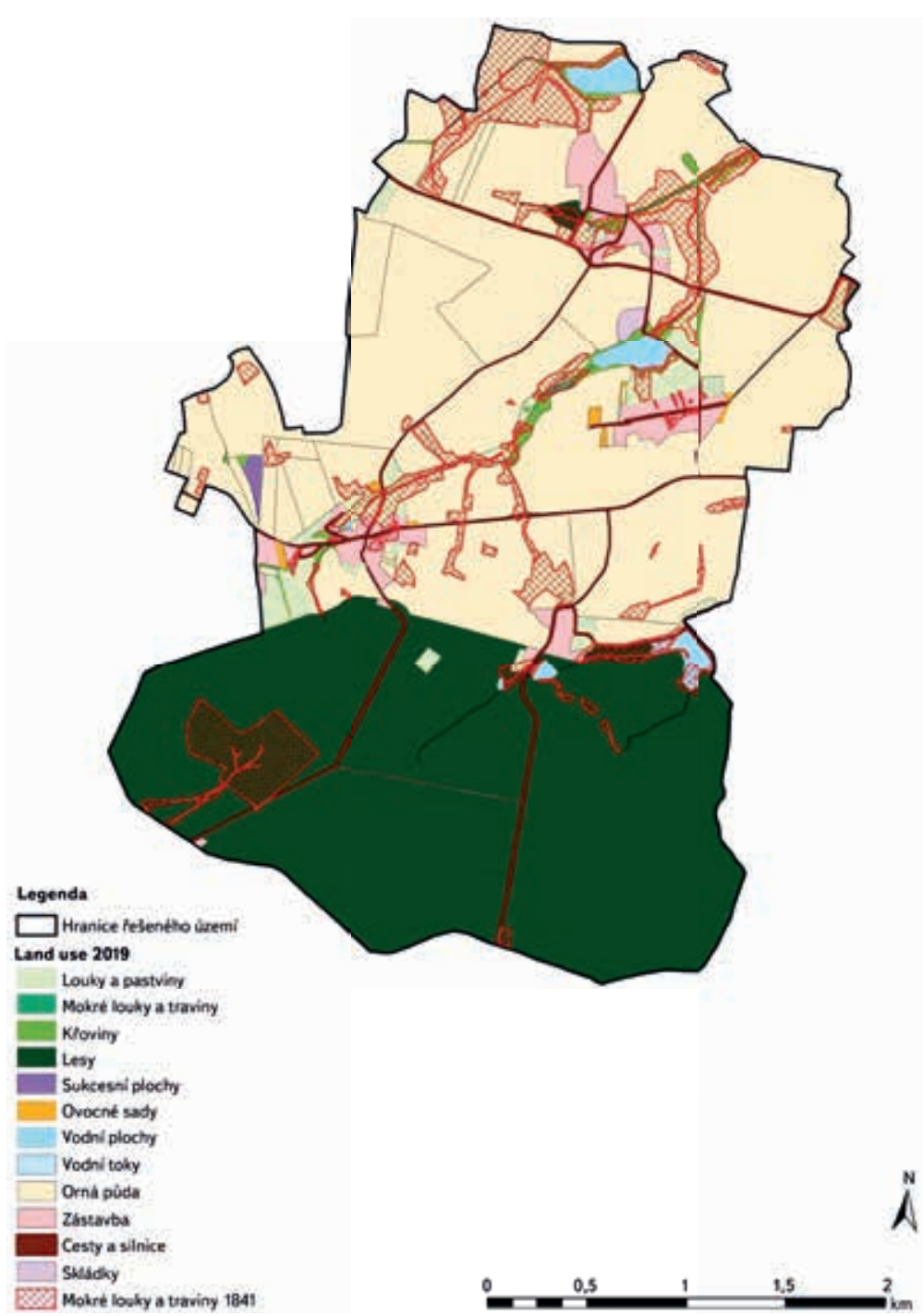

Obr. 11. Zobrazení historických mokrých luk na podkladě současného land use v k. ú. Staňkovice

Fig. 11. Historical land use of wet meadows based on current land use in cadastral territory of Staňkovice

těžebním prostoru bývalé cihelny ve Chmelišti. Těžba v této části cihelny byla ukončena žrejmě začátkem 90 . let 20. stol. Její plocha měla být rekultivována a navrácena zemědělskému využití. Jelikož k tomu však bezprostředně po ukončení těžby nedošlo, byla zde plocha ponechána sukcesi. Když se začalo o rekultivaci (zavezení prostoru bývalé cihelny) opět jednat, již by to znamenalo velkou újmu pro prírodu. Proto byla nejcennější část cihelny v roce 2010 vykoupena. V současné době probíhají jednání o trvalém vyjmutí pozemků ze zemědělského půdního fondu a změně rekultivačního plánu. Český svaz ochránců přrirody vlastní souvislé území o celkové výměře 3,7 ha, zahrnující nejcennějšs část bývalé cihelny. Zde management plánuje nutné kroky pro zachování nejvzácnějších druhů, jež se v bývalé cihelně vyskytují, tedy částečně redukovat křoviny a rákosiny, které celou plochu postupně zarůstají, a zanášející se tůňky občas prohloubit či na vhodném místě vytvořit nové [18].

Při hodnocení hypotézy $\mathrm{H1}$, kde byl potvrzen markantní úbytek mokřadů, mohlo dojít k mírnému zkreslení výsledků použitou metodikou hodnocení podle land use. Některé podmáčené lokality by se v případě hodnocení podle land cover mohly zařadit do mokrých luk, prípadně sukcesních ploch. Nicméně kromě výše zmiňované lokality $v$ k. ú. Rašovice se jednalo o několik drobných plošek do velikosti 0,01 ha. Pokud jde o podíl zastoupení současných mokrých

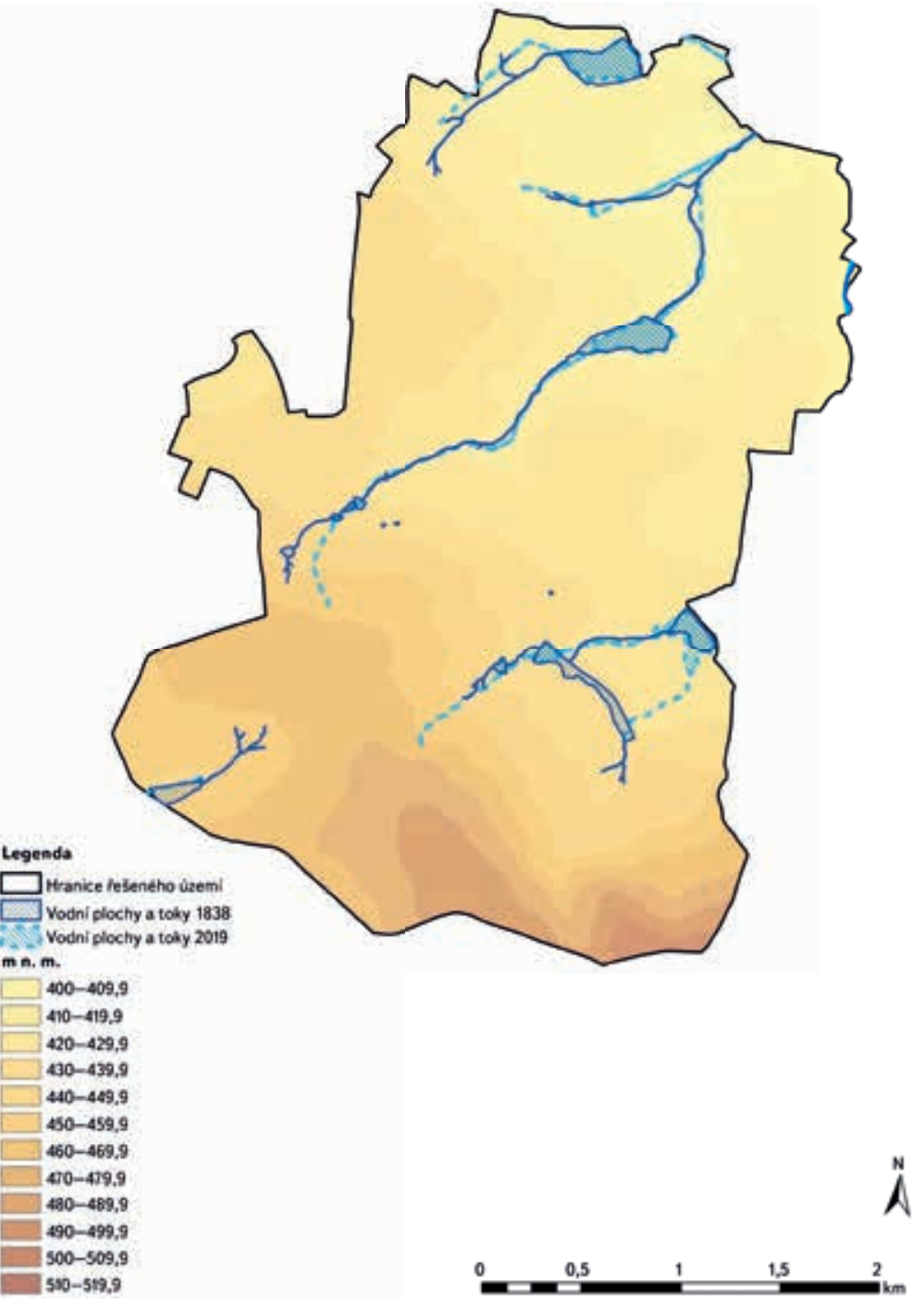

Obr. 12. Porovnání historické a současné lokalizace vodních ploch a tokư v k. ú. Staňkovice

Fig. 12. The comparison of historical and current localization of water reservoirs and watercourses in cadastral territory of Staňkovice

luk k historickým mokrým loukám, potvrdil se velký rozdíl u k. ú. Rašovice (MT4), a to 7,9 \% oproti ostatním k. ú. patřícím do MT2. V k. ú Staňkovice byl tento podíl jen 0,9 \% a ve společně hodnoceném k. ú. Chmeliště a Žíšov pak 2,5\%. Větší zastoupení v rámci těchto území bylo zřejmě způsobeno lokalizací vodního toku Výrovka. V k. ú. Mančice byl pak tento podíl větší, činil 3,8 \%. Nicméně tento rozdíl byl zrejmě způsoben tím, že se jednalo pouze o jednu lokalitu současných mokrých luk a celková plocha historických mokrých luk v tomto území byla menší (7,5 \% plochy k. ú.) než v ostatních územích (9,8-12,7\%).

Při stanovení hypotézy H2 ohledně land use orná pưda bylo téměř jisté, že průměrné velikosti plošky se výrazně zvýší a jejich počet výrazně poklesne, avšak jak ukázaly mapy stabilního katastru v případě k. ú. Chmeliště a na současném k. ú. Bláto, tato skutečnost není v některých lokalitách tak samozřejmá. $\checkmark$ případě celkové rozlohy land use orná půda již vstupují do hry další faktory a $\vee$ prípadě k. ú. Rašovice nebyla tato hypotéza potvrzena - podíl současné orné půdy k historické je 98,5%. Zde hrálo velkou roli zalesňování původních ploch orné půdy a velký rozvoj zástavby. Historické plochy mokrých luk tu byly ve větší míře nahrazovány nejen ornou půdou, ale také křovinami a „suchými“ loukami, a nekompenzovaly tak úbytek orné půdy. Obdobně také v k. ú Chmeliště a Žíšov je podíl současné orné půdy k historické 105,3 \%. 
Tady je důvodem převažující změna land use mokré louky v "suché" louky a křoviny v nivě Výrovky a také výrazný nárůst jak obytné, tak průmyslové zástavby (cihelna). Jedním z trendů je obytná zástavba na orné půdě, ovšem v př́padě k. ú. Chmeliště je tato orná půda lokalizována částečně i na místě historických mokrých luk. V k. ú Mančice a Staňkovice byl nárůst plochy orné půdy opravdu výrazný (12,1\%, resp. $25,8 \%)$.

Při hodnocení hypotézy H4 bylo potvrzeno zkrácení délky vodních toků s výjimkou k. ú. Rašovice, kde však byla tato skutečnost zřejmě dána pouze způsobem zakreslování drobných vodních toků na mapách stabilního katastru (viz níže). Ovšem toto zkrácení nebylo nijak výrazné. Částečně to vzniklo také tím, že na řešeném území se vyskytují neregulované úseky vodních toků (Výrovka mezi k. ú. Chmeliště a Žíšov), a zároveň tím, že napřimování vodních toků bylo zaznamenáno již na mapách stabilního katastru. Nicméně zřejmě hlavním důvodem je skutečnost, že v řešeném území došlo ke snížení rozlohy vodních ploch. Ty byly samozřejmě budovány na vodních tocích. Z toho plyne, že priibližně v délce zaniklé vodní plochy $v$ hodnocení současného land use přibyl „nový“ vodní tok, a tím bylo také eliminováno zkrácení vodních toků vlivem jejich napřimování a likvidace meandrů. To neplatí pro k. ú. Mančice, kde se nevyskytovaly žádné vodní plochy a protéká zde jen jeden vodní tok.

Ve výsledcích se též objevovala menší plocha vodních toků v současnosti oproti minulosti, ačkoli poměr délek současných a historických vodních toků tomu neodpovídal. Bylo to způsobeno napřimováním vodních toků od 50. let minulého století, kdy při tomto procesu došlo k zahlubování a zúžení původních vodních koryt. To mělo za následek mj. i přeměnu mokrých luk v louky "suché" vlivem poklesu hladiny podzemní vody v těchto lokalitách. K napřimování vodních toků a zvětšování ploch orné půdy docházelo již v dobách mapování stabilního katastru. Príkladem je historické k. ú. Chmeliště, jež bylo typickým územím obhospodařovaným statkem a již v polovině 19. století bylo zřetelně více ovlivněno lidskou činností než ostatní k. ú. v řešeném území. Tato skutečnost platí i pro část historického k. ú. Staňkovice (nynější k. ú. Bláto), kde bylo také sídlo statku. Mapy stabilního katastru jsou věrohodné, nicméně v zobrazování drobných vodních toků mají nedostatky. V některých lokalitách, kde je zjevné (jsou tam lokalizovány mokré louky v konfiguraci indikující vodní tok nebo prameniště), že by tam měl být drobný vodní tok zakreslen, tam není. Bud’ šlo o plošné prameniště, kde žádný hlavní tok neexistoval, nebo prostě některé drobné toky byly zakreslovány až od určité šiřky. Zde je vidět tento jev zejména na území Rašovic (obr. 2, 3 a 4) a Žíšova (obr. 7, 8 a 9).

\section{ZÁVĚR}

Hlavní myšlenkou článku je zviditelnění tématu potenciálu mokřadů a zamokřených ploch v zemědělské krajině s představením konkrétních lokalit s možností jejich obnovy. Mapy stabilního katastru jsou velmi přesným zdrojem informací o stavu tehdejší krajiny, zejména pro lokalizaci mokřadů a ostatních vodních prvků i pro představu o krajině téměř neregulovaných vodních toků. Byla potvrzena hypotéza $\mathrm{H} 1$. Ze současné krajiny v řešeném území téměř vymizely mokré louky. Toto snižení je výraznější v části patřící do klimatického regionu MT2 (k. ú. Staňkovice, Chmeliště, Žíšov a Mančice), kde současné mokré louky zaujímají 0,9, resp. 2,5, resp. 3,8 \% plochy, kterou zaujímaly historické mokré louky. V k. ú. Rašovice patřící do klimatického regionu MT4, který je srážkově bohatší, zaujímají nyní mokré louky 7,9 \% plochy mokrých luk historických. Byla potvrzena také hypotéza $\mathrm{H} 2$, v celém řešeném území je u orné půdy trendem nárůst její celkové rozlohy, výrazný nárůst průměrné velikosti plošky a zároveň snížení počtu plošek. S výjimkou k. ú. Rašovice, kde výměra orné půdy činí 98,5% její historické rozlohy. Dalším trendem, potvrzujícím hypotézu H3, je snížení rozlohy vodních ploch. Hypotéza H4 týkající se zkracování délky vodních toků byla v řešeném území potvrzena s výjimkou k. ú. Rašovice. Ovšem tyto rozdíly nebyly nijak markantní. Zároveň také došlo k výraznému snižení plošného zastoupení vodních toků. Pravděpodobné důvody tohoto stavu jsou zmíněny $\checkmark$ diskuzi. Získané informace lze obecně využít při plánování krajiny, zejména s ohledem na obnovu mokřadů ve vhodných lokalitách. Výsledky této práce Ize aktuálně využít i pro tzv. boj se suchem a pro zmírnění následků povodní jakožto reakci na probíhající klimatické změny. Zejména při obnově krajiny za účelem zadržování vody v krajině s odkazem na historický způsob využití území (land use).

\section{Literatura}

[1] FARINA, A. Principles and methods in landscape ecology. Springer, Netherlands, 2006, 229 p

[2] KUPKA, J. Krajiny kulturni a historické: vliv hodnot kulturni a historické charakteristiky na krajinný ráz naši krajiny. Praha: České vysoké učení technické v Praze, 2010. ISBN 978-80-01-04653-1.

[3] Mokřady, z. s. Mokřady - ochrana a management [on-line]. [cit. 23. dubna 2021]. Dostupné z: <http://www.mokrady.wbs.cz>

[4] MEYER, B. K., VANCE, R. K., BISHOP, G. A., DEOCAMPO, D. M. Origin and Dynamics of Nearshore Wetlands: Central Georgia Bight, USA. Wetlands (2015) 35, pp. 247-261

[5] MANDER, U., KUUSEMETS, V., LOHMUS, K., MAURING, T. Efficiency and dimensioning of ripparian buffer zones in agricultural catchmens. Ecological Engineering 8(4), 1997, pp. 299-324

[6] MAITRE, W., COSANDEY, A.-C., DESAGHER, E., PARRIAUX, A. Effectiveness of groundwater nitrate removal in a river riparian area: the importance of hydrogeological conditions. Journal of Hydrology 278 (1-4), 2003, pp. 76-93

[7] LANE, R. R., MASHRIQUI, H. S., KEMP, G. P., Day, J. W., DAY, J. N., HAMILTON, A. Potential nitrate removal from a river diversion into a Mississippi delta forested wetland. Ecological Engineering 20(34), 2003, pp. 237-249

[8] MAYER, W. B., TURNER, B. L. Human population growth and global land-use/land-cover change. Ann. Rev. Ecol. Syst. 23, 1992, pp. 39-61

[9] HATTERMANN, F. F., KRYSANOVA, V., HESSE, C. Modelling wetland processes in regional applications. Hydrological Science Journal 53(5), 2008, pp. 1001-1012

[10] PREMALATHA, M., TASNEEM, A., ABBASI, S. A. Applications of GIS in Wetland Management: An Overview. Research journal of chemistry and environment, 14 (4), 2010, pp. 87-102

[11] Komplexní průzkum půd. Výzkumný ústav meliorací a ochrany půdy, v. v. i. [on-line]. [cit. 24. května 021]. Dostupné z: <https://kpp.vumop.cz>

[12] Geoportál SOWAC-GIS. Výzkumný ústav meliorací a ochrany půdy, v. v. i. [on-line]. [cit. 28. května 2021]. Dostupné z: <https://geoportal.vumop.cz>

[13] Vyhláška č. 227/2018 Sb. o charakteristice bonitovaných půdně ekologických jednotek a postupu pro jejich vedení a aktualizaci

[14] RICHTER, P. Analýza vývoje krajiny v zemědělských oblastech na př́kladu k. ú. Rašovice. Acta Pruhoniciana 2011, 99, pp. 29-39

[15] RICHTER, P. Trajektorie vývoje mokřadů $\vee$ horní části povodí Výrovky za uplynulých 180 let. Vodohospodárské technicko-ekonomické informace, 2020, 62 (6), pp. 20-26. ISSN 0322-8916.

[16] Archivní mapy Ústředního archivu zeměměřictví a katastru [on-line]. [cit.10. řijna 2020]. Dostupné z: <https://archivnimapy.cuzk.cz>

[17] Geoportál ČúZK/ Prohlížecí služby - WMS [on-line]. [cit. 12. března 2021]. Dostupné z: https:// geoportal.cuzk.cz/(S(Icsguqwsq1my1rvbg3qy5suw))/Default.aspx?mode=TextMeta\&side=wms. verejne\&text=WMS.verejne.uvod\&head_tab=sekce-03-gp\&menu=311

[18] Místo pro prírodu. Zachráněné lokality. Cihelna Chmelište [on-line]. [cit. 1. června 2021]. Dostupné z: < http://www.mistoproprirodu.cz/zachranene-lokality/cihelna-chmeliste/>

\section{Autor}

Ing. Pavel Richter, Ph.D.

凶pavel.richter@vuv.cz

ORCID: 0000-0001-6338-3481

Výzkumný ústav vodohospodářský T. G. Masaryka

Příspěvek prošel lektorským řizením.

DOI: 10.46555/VTEI.2021.05.004 
THE ANALYSIS OF AGRICULTURAL

LANDSCAPE DEVELOPMENT SHOWN

ON SELECTED CADASTRAL DISTRICTS

IN THE UPPER PART OF THE VÝROVKA

RIVER BASIN

\section{RICHTER, P.}

TGM Water Research Institute

Keywords: archive maps - GIS - land use - wetlands -

water in the landscape - agricultural management

This article compares the current land use and landscape structure with the historic layout from the maps of the Imperial Imprints of the Stable Cadastre in selected cadastral areas with predominantly agricultural land. It outlines the possibilities of using the analysis of the historical development for the purposes of landscape restoration in agricultural areas, particularly wetland ecosystems and watercourses. 